УДК 332.14:336.143:005.322.5

DOI: https://doi.org/10.26642/jen-2020-2(92)-114-120

\author{
О.М. Бондаревська, к.е.н. \\ Національний університет \\ «Полтавська політехніка імені Юрія Кондратюка»
}

\title{
Ідентифікація впливу бюджетної децентралізації на економічну безпеку регіону
}

\begin{abstract}
Гарантування економічної безпеки регіону шляхом посилення впливу бюджетної децентралізації є одним із пріоритетних напрямів сучасного етапу розвитку України. У статті проаналізовано групи ризиків економічної безпеки регіону, щьо спричинені впровадженням реформи бюджетної децентралізащії (пов'язані з територіальними аспектами бюджетної децентралізації, викликані ефектом масштабу, управлінські, економічні, фінансові). Визначено основні переваги та недоліки бюджетної децентралізації порівняно із централізованою системою міжбюджетних відносин. Визначальною перевагою бюджетної децентралізації $\epsilon$ можливість збільшення алокативної ефективності наданих суспільних послуг. Систематизовано ризики впровадження бюджетної децентралізації в Україні, проведено їх аналіз та окреслено напрями щзодо запобігання. У результаті аналізу переваг, недоліків та ризиків децентралізаційних процесів у бюджетній системі України доцільно стверджувати, щчо бюджетна децентралізація більшою мірою сприяє зростанню дохідного потенціалу регіонів, якісному й обтрунтованому задоволенню сочіальних потреб населення на місцевому рівні, забезпеченню обтрунтованого розподілу фінансових ресурсів між окремими територіальними утвореннями. Доведено, що бюджетна децентралізація позитивно впливає на рівень економічної безпеки регіону, сприяе стимулюванню до його фінансової автономії, пошуку додаткових власних ресурсів, активізації внутрішнього потенціалу розвитку, дозволяє балансувати потреби та можливості регіонів.
\end{abstract}

Ключові слова: децентралізація; бюджетна децентралізація; ризик; переваги; недоліки; економічна безпека регіону.

Актуальність теми. Економічна безпека такого складного об’єкта, як регіон не може визначатися тільки станом економічної системи території. Досягненню економічної безпеки на регіональному рівні перешкоджає низка невирішених проблем. Так економічній безпеці регіонів загрожують не тільки правова нерозв'язаність багатьох питань, руйнування науково-технічного потенціалу, відсутність системи охорони навколишнього середовища, міграція кадрового потенціалу, тінізація економіки, зростання економічної злочинності, територіальні диспропорції, низька професійна компетенція управлінських кадрів регіональних органів управління, але й головне - відсутність безпекових пріоритетів у їхньому соціально-економічному розвитку.

Гарантування економічної безпеки регіонів має бути найважливішою функцією держави в умовах бюджетної децентралізації, адже саме на місцевому рівні є можливість протистояти окремим ії загрозам. Реалізація можливостей щодо досягнення рівня економічної безпеки регіону перебуває під впливом багатьох чинників (загроз): економічних, політичних, психологічних, науково-технічних, соціальних і багатьох інших, під якими розуміють причинно-наслідкові зв'язки, що існують у системі гарантування безпеки і є рушійними силами, спонукальними мотивами перетворення можливості в дійсність і максимізації зусиль у використанні внутрішніх резервів.

Аналіз останніх досліджень та публікацій, на які спирається автор. Базові концепції бюджетної децентралізації досліджували у своїх працях зарубіжні вчені, а саме: М.Белл, Р.Масгрейв, В.Оутс, Ч.Тібо, А.Шнайдер та інші. Проблемі бюджетної децентралізації, підвищенню фінансової самостійності регіонів присвятили дослідження вітчизняні вчені: В.Андрущенко, Д.Боголєпов, Г.Возняк, І.Волохова, Ю.Гуменюк, Т.Заяць, Н.Свтушенко, І.Луніна, О.Сунцова, В.Федосов, С.Юрій та інші. Науковці доводять, що реально фінансову самостійність місцевих органів влади можна забезпечити шляхом децентралізації та ефективного розподілу фінансових ресурсів.

Метою статті $є$ дослідження впливу бюджетної децентралізації як одного із пріоритетних напрямів сучасного етапу розвитку України на рівень економічної безпеки регіону.

Викладення основного матеріалу. У сучасних умовах економічна політика має бути спрямована на зміцнення фінансового стану регіональних суб’єктів господарювання та збільшення їхньої самодостатності шляхом реалізації бюджетної децентралізації. За економічним змістом бюджетна децентралізація покликана підвищувати ефективність функціонування бюджетної системи за рахунок передачі повноважень на місця й самостійності в ухваленні рішень під час формування доходів та використання бюджетних коштів [1]. Децентралізація бюджетних коштів посилює стимули до ліквідації тіньового бізнесу на окремій території, оскільки більш прозорим стає механізм розподілу коштів і більш 
відкритими політичні рішення в інтересах територіальної громади, що суттєво зміцнить економічну безпеку на регіональному рівні. Раціональний підхід до витрачання бюджетних коштів призводить до мінімізації бюджетного дефіциту. Вдало проведена бюджетна децентралізація сприяє нарощенню фінансового потенціалу території, активізації інвестиційної діяльності, стимулюванню підприємницької активності, що в підсумку зміцнює економічний потенціал регіону [5, 7].

У той же час, характеризуючи бюджетну децентралізацію як позитивний прогресивний процес, варто враховувати й проблеми, які вона може створити. Зокрема, в умовах децентралізації складно узгоджувати локальні потреби окремих територіальних громад 3 макроекономічними цілями всієї держави. Надмірна децентралізація бюджетної системи ускладнює реалізацію державою такої функції, як стабілізація й перерозподіл доходів через бюджет та управління бюджетним процесом в цілому, оскільки центральному уряду важче децентралізувати відповідальність за джерела оподаткування, ніж за видатки місцевих бюджетів. За умов фінансово-економічної нестабільності цілі державної і регіональної влади в питанні реалізації бюджетної політики можуть мати різні пріоритети, а вирівнювання бюджетної забезпеченості бути неефективним, що призведе до посилення диференціації регіонального розвитку. Передача видаткових повноважень регіонам та права самостійного встановлення місцевих податків вигідна насамперед регіонам з високим рівнем доходів, адже можливості надавати суспільні послуги у «багатих регіонів» і надалі будуть вищими, ніж у «бідних регіонів», тобто економічно потужні регіони й далі ставатимуть сильнішими.

Наступна група ризиків економічної безпеки регіону, що пов'язана 3 територіальними аспектами бюджетної децентралізації, виходить з особливостей виробництва і надання локальних суспільних благ на місцевому рівні. Йдеться про ризик втрат, викликаних ефектом масштабу і зовнішніми ефектами. Тут фактично ставиться питання про мінімально допустимі розміри територіального утворення, що має самостійні органи влади й фінансову компетенцію. Центром проблеми $є$ співвідношення локальних суспільних благ (територіальних послуг), ефектів, які виникають, та ефективності їх виробництва.

Під час аналізу ризиків втрат, викликаних ефектом масштабу, враховуються як власне об'єктивні передумови отримання економії на масштабі, так і можливий спектр благ та послуг певної якості, що надається місцевими громадами на певній території. Співвідношення локальних (місцевих) ефектів від надання суспільних послуг та ефективності їх створення викликають ризики, обумовлені «ефектом масштабу»: скорочення витрат на одиницю наданої послуги при збільшенні обсягів наданих послуг (вартість послуги зменшується при збільшенні охочих їі отримати). Цей аргумент використовується під час обгрунтування доцільності об'єднання адміністративно-територіальних одиниць щодо мінімального розміру адміністративно-територіальної одиниці, під час якого співвідношення ціна / якість суспільної послуги буде оптимальним, а соціально-економічний ефект - максимальним.

Не менш важливими ризиками, які можуть виникнути під час проведення бюджетної децентралізації, $\epsilon$ намагання центральної влади зберегти контроль за розподілом коштів, недостатність коштів на місцевому рівні й нездатність їх залучити, неспроможність місцевих органів самостійно та ефективно використовувати кошти. Крім фінансових ризиків бюджетної децентралізації, слід виокремити ще одну групу ризиків - управлінські, що пов'язані з низькою кваліфікацією управлінського апарату органів місцевого самоврядування, домінуванням особистих інтересів над суспільними, невідповідністю формування місцевих бюджетів цілям та завданням соціально-економічного розвитку територій, що в підсумку знівелює використання потенціалу бюджетної децентралізації та призведе до зниження ефективності функціонування суспільного сектору.

В умовах децентралізації зростає ризик виникнення «інституціональних пасток», обумовлених неузгодженістю дій різних гілок влади чи конфліктом їхніх інтересів, щодо розв'язання локальних проблем на територіальному рівні. Про це, власне, свідчить перший досвід об'єднання територіальних громад, значна частка яких не змогла належним чином організувати місцеве самоврядування, зосередити зусилля на задоволенні першочергових потреб з урахуванням наданих повноважень і функцій [6].

Серед економічних ризиків варто звернути увагу на ризики виникнення конфлікту за цілями перерозподілу доходів і макроекономічної стабільності [4]. Модель бюджетної децентралізації передбачає вибір пріоритетів загальнонаціональної політики держави між такими цілями, як досягнення економічної ефективності, соціальної справедливості та макроекономічної стабільності. Суперечливість поєднання цих цілей в умовах бюджетної децентралізації спричиняє ефект «дилеми трикутника» [11].

Варто зазначити, що на практиці жодна модель бюджетної децентралізації не заперечує міжбюджетне вирівнювання соціально-економічного розвитку. До того ж, методи міжбюджетного регулювання у поєднанні з територіальною різноманітністю умов і переваг у наданні локальних суспільних благ здатні мінімізувати ризики посилення диспропорцій територіального розвитку. У той же час, якщо у процесі бюджетної децентралізації поглиблюється розрив у соціально-економічному розвитку територій, то потрібно оцінювати динаміку бюджетної децентралізації, іiі вплив на територіальний розвиток, за результатами яких розробляти додаткові спеціальні заходи адаптаційного та стимулюючого характеру. У практичних рішеннях з питань децентралізації такі цілі накладаються на 
вертикальний і горизонтальний дисбаланси бюджетної системи, що вимагає розроблення ефективного інструментарію вирішення цієї проблеми.

Вертикальна незбалансованість характеризується невідповідністю податкових доходів видатковим зобов'язанням між рівнями влади в бюджетній системі держави, а горизонтальна незбалансованість різницею в рівнях соціально-економічного розвитку (і відповідно у бюджетному потенціалі) територій. Ці чинники $є$ системою обмежень для одночасного досягнення макроекономічних цілей розвитку й обумовлюють важливість розроблення збалансованої системи міжбюджетних відносин у всьому іï прояві: організаційно-правове забезпечення, система розподілу доходів, витрат і трансфертів, залучення позикових коштів на регіональному та місцевому рівнях.

Логічність такого підходу є досить аргументованою:

соціально-економічний дисбаланс територіального розвитку тільки посилиться, якщо для забезпечення макроекономічної стабільності та економічної ефективності буде використовуватися зростання податкової автономії адміністративних територіальних громад, а отже, це призведе до зростання соціальної напруженості в суспільстві;

зниження макроекономічної стабільності стане суттєвим негативним наслідком бюджетної децентралізації при концентрації управлінських і фінансових рішень на досягненні цілей підвищення соціальної справедливості та економічної ефективності, тому що можливий інструментарій у цьому випадку зводиться до посилення податкової автономії територій під час одночасного зростання нецільових дотацій;

- підтримка макроекономічної стабільності та підвищення соціальної справедливості в умовах бюджетної децентралізації досягаються шляхом централізації податкової бази при одночасному зростанні нецільових дотацій, що, безумовно, знижує горизонтальний дисбаланс розвитку територій, але не забезпечує економічну ефективність ні в розподілі обмежених ресурсів, ні у сфері виробництва суспільних благ.

3 огляду на таку логіку переваги і недоліки кожного варіанта під час вибору моделі бюджетної децентралізації дозволяють охарактеризувати цей процес, в тому числі, і як політичний. Вибір моделі децентралізації зумовлює вихідні можливості й потенціал надання та фінансування локальних суспільних потреб самостійними адміністративними територіальними одиницями, вимагає формування як ефективної системи міжбюджетних трансфертів для згладжування диспропорцій соціальноекономічного розвитку, так і ефективного фінансового контролю на всіх рівнях управлінської вертикалі.

У територіальному аспекті (з точки зору децентралізованого надання локальних суспільних благ) економічні ризики бюджетної децентралізації зводяться, насамперед, до істотних територіальних відмінностей у розподілі ресурсів та доходів, природних і соціальних особливостей території. Інколи це призводить до того, що бюджетна децентралізація фактично перешкоджає вирівнюванню соціальноекономічного розвитку регіонів. Проте це твердження є не зовсім коректним, адже відсутній прямий причинно-наслідковий зв'язок між бюджетною децентралізацією та поглибленням диспропорційності територіального розвитку, тобто ризик можливий, але не визначений. Потрібне своєчасне коригування або зміна обраної моделі бюджетної децентралізації. Це вкотре підтверджує тезу про те, що бюджетна децентралізація не є остаточним результатом; це динамічна система і розвивається вона як процес, який підпорядковується певній логічній послідовності та має безліч практичних рішень.

У зв'язку з цим виникають і фінансові ризики бюджетної децентралізації, що зумовлені проблемами і можливостями фінансового забезпечення суспільних благ та послуг локального характеру. Ці ризики можуть виявлятися у наповненні податкових надходжень на відповідній території для фінансового забезпечення локальних суспільних благ (податкова конкуренція, «втеча оподатковуваної бази» й ефекти «переливів оподаткування»), підвищенні вартості суспільних благ, невідповідності інструментів фінансовобюджетної координації функціональній відповідальності органів влади у наданні суспільних благ тощо.

Бюджетна децентралізація не заперечує ймовірності виникнення нових фінансових розривів через невідповідність потреб і реальних фінансових можливостей територій щодо наповнення місцевого бюджету [5]. Перехід від централізованої системи міжбюджетних відносин до децентралізованої викликаний низкою суттєвих недоліків бюджетної централізації. До таких недоліків можна зарахувати обмежений вплив органів місцевої влади на формування дохідної частини бюджету, неможливість прогнозування видатків на перспективу, відсутність мотивації до нарощування дохідної бази місцевих бюджетів, непрозорість розподілу дотацій місцевих бюджетів, відсутність відповідальності за виконання місцевих бюджетів тощо.

Перевагою бюджетної децентралізації є можливість збільшення алокативної ефективності наданих суспільних послуг. Тобто органи місцевого самоврядування можуть підвищити добробут населення за рахунок задоволення індивідуальних потреб. При цьому суспільні послуги мають максимально відповідати інтересам населення і бути якісними, а витрати на їх надання - мінімальними. Іншим аргументом на користь бюджетної децентралізації $\epsilon$ їі здатність стимулювати горизонтальну й вертикальну бюджетну конкуренцію, що сприятиме поліпшенню якості наданих послуг [2]. 
У той же час бюджетна децентралізація, враховуючи як політичні, так і економічні аспекти, має забезпечити низку переваг порівняно із централізованою системою міжбюджетних відносин (табл. 1).

Таблиия 1

Переваги та недоліки бюджетної децеентралізації

\begin{tabular}{|c|c|c|}
\hline $\begin{array}{l}\text { № } \\
\text { 3/II }\end{array}$ & Перевага & Недолік \\
\hline 1 & $\begin{array}{l}\text { Можливість збереження } \\
\text { макроекономічної стабільності }\end{array}$ & $\begin{array}{l}\text { Поглиблення диференціації у рівнях соціально- } \\
\text { економічного розвитку регіонів }\end{array}$ \\
\hline 2 & $\begin{array}{lcc}\text { Зростання } & \text { горизонтальної } & \text { та } \\
\text { вертикальної бюджетної конкуренції } & \end{array}$ & $\begin{array}{l}\text { Мінімізація ефективності контролю центральної } \\
\text { влади за бюджетним процесом на регіональному } \\
\text { рівні }\end{array}$ \\
\hline 3 & $\begin{array}{l}\text { Забезпечення фінансової самостійності за } \\
\text { рахунок оптимізації дохідних джерел та } \\
\text { удосконалення } \\
\text { адміністрування }\end{array}$ & $\begin{array}{l}\text { Проблема узгодження локальних потреб регіонів } 3 \\
\text { макроекономічними цілями держави }\end{array}$ \\
\hline 4 & $\begin{array}{lcr}\text { Стимулювання } & \text { органів } & \text { місцевого } \\
\text { самоврядування } & \text { до } & \text { нарощування } \\
\text { власного бюджетного потенціалу }\end{array}$ & $\begin{array}{l}\text { Низька кваліфікація управлінського апарату } \\
\text { органів місцевого самоврядування, домінування } \\
\text { особистих інтересів над суспільними, } \\
\text { невідповідність формування місцевих бюджетів } \\
\text { цілям та завданням соціально-економічного } \\
\text { розвитку регіону }\end{array}$ \\
\hline 5 & $\begin{array}{l}\text { Раціональне використання бюджетних } \\
\text { коштів, мінімізація бюджетного дефіциту }\end{array}$ & $\begin{array}{l}\text { Зростання витрат на надання суспільних послуг } \\
\text { для невеликих територій у випадку поширення } \\
\text { «ефекту масштабу» }\end{array}$ \\
\hline 6 & $\begin{array}{l}\text { Наближеність місцевих органів влади до } \\
\text { населення }\end{array}$ & \\
\hline 7 & $\begin{array}{lrr}\text { Посилення } & \text { відповідальності } & \text { органів } \\
\text { місцевого } & \text { самоврядування } & \text { перед } \\
\text { громадою } & & \\
\end{array}$ & \\
\hline 8 & Активізація інвестиційної діяльності & \\
\hline 9 & $\begin{array}{l}\text { Забезпечення надання } \\
\text { суспільних послуг }\end{array}$ & \\
\hline
\end{tabular}

На особливу увагу заслуговує випадок посилення бюджетної децентралізації, який може супроводжуватися «зовнішніми» ефектами «переливу і переповнення». Суть цього явища полягає у тому, що, якщо за надану суспільну послугу не можна отримати належну плату, то іiі надаватимуть не в повному обсязі. Як наслідок - нераціональне використання коштів (виникає дисбаланс між тими, хто платить, і тими, хто користується послугою) [10].

За певних обставин бюджетна децентралізація може мати низку інших фінансових ризиків i небезпек, що потребуватимуть вирішення у майбутньому:

1. Приховані ризики містять у собі задекларовані процеси проведення добровільного об'єднання місцевих громад, розширення повноважень, зокрема користування земельними ресурсами, зміна адміністративно-територіального устрою країни, адже практичне їх втілення відбувається іноді шляхом примусового об'єднання громад та приєднання територій усупереч принципам добровільності, законності, прозорості й відкритості;

2. Проблемою при зміні адміністративно-територіальних меж місцевих громад (їх об'єднань) стане вирішення правової та інституційної узгодженості й відповідальності щодо об'єктів комунальної власності, а найважливіше, - забезпечення життєдіяльності населення внаслідок децентралізації об'єктів житлово-комунального господарства;

3. Запроваджені зміни (вилучення повноважень в обласних державних адміністрацій з формування обласних бюджетів, передача окремих установ соціально-культурної сфери на утримання місцевих бюджетів, впровадження нової системи вирівнювання) у нинішніх умовах можуть мати високий ризик розбалансування державного бюджетного процесу за рахунок закладання в місцеві бюджети завищених витрат;

4. Через відсутність портфельного підходу до формування дохідної бази місцевих бюджетів виникають додаткові загрози для фінансової автономії місцевого самоврядування, а недостатня 
обгрунтованість алгоритму визначення видаткових потреб органів місцевого самоврядування та їх пріоритетів спричиняє виникнення й збільшення вертикальних фіскальних дисбалансів;

5. Обсяг власних ресурсів є недостатнім для ефективного виконання бюджетних послуг у належному обсязі та якості, що збільшує залежність від державного бюджету й рівень централізації. Значна залежність місцевих бюджетів від державного бюджету може бути сигналом про незбалансованість розподілу повноважень між рівнями управління і системи міжбюджетних відносин, а також про проблеми 3 нарощування дохідної частини місцевих бюджетів через інституційну та економічну слабкість окремих територій.

У зв'язку з цим, одним із пріоритетних завдань для органів місцевого самоврядування має бути підвищення значення місцевих податків та зборів, досягнення їх максимально можливої мобілізації. Це сприятиме посиленню фінансової стійкості та самостійності місцевих бюджетів, ефективності використання наявного фіскального потенціалу відповідних територій i, як наслідок, забезпечить поліпшення рівня та якості послуг, що надаються жителям громад. Формування значної частини власних доходів місцевих бюджетів прямо залежить від того, наскільки ефективно органи місцевого самоврядування зможуть організувати весь комплекс робіт із запровадження й мобілізації місцевих податків і зборів.

Існуючий алгоритм розмежування між бюджетами податку на доходи фізичних осіб може стати причиною втрат місцевими бюджетами України (особливо у бюджеті м. Києва, обласних та інших бюджетах зі значними обсягами надходжень за цим податком), які не компенсуються коштами з інших джерел. Втративши стабільне джерело надходжень, місцеві бюджети натомість отримають податки, надходження від яких є менш прогнозованими. Зокрема, надходження від податку на прибуток не можна спрогнозувати, особливо в нинішніх кризових умовах, коли багато підприємств є збитковими, а рівень тінізації економіки (за статистикою) сягає $47 \%$.

Відсутність системи стандартів надання суспільних послуг буде каталізатором недостатньої прозорості процедур формування та виконання видаткової частини місцевих бюджетів відповідними місцевими фінансовими органами, зниження їхніми ініціативи щодо пошуку резервів збільшення надходжень до бюджетів, недостатньо ефективного використання бюджетних коштів їх розпорядниками.

Систематизація наведеного вище переліку ризиків впровадження бюджетної децентралізації в Україні наведена в таблиці 2.

Таблиия 2

Систематизачія ризиків впровадження бюджетної деиентралізачї̈ в Україні

\begin{tabular}{|c|c|c|}
\hline $\begin{array}{l}\text { № } \\
\text { 3/II }\end{array}$ & Ризик & Його характеристика \\
\hline 1 & 2 & 3 \\
\hline 1 & $\begin{array}{c}\text { Ототожнення } \\
\text { децентралізації } 3 \\
\text { об’єднанням громад }\end{array}$ & $\begin{array}{l}\text { Підхід до децентралізації має бути диференційованим, а до } \\
\text { створення ОТГ - реальним і рівноправним }\end{array}$ \\
\hline 2 & $\begin{array}{c}\text { Створення надто великих } \\
\text { територіальних громад }\end{array}$ & $\begin{array}{l}\text { Мета реформи - наблизити послуги до громадян, а не } \\
\text { віддалити їх }\end{array}$ \\
\hline 3 & $\begin{array}{c}\text { Форсування процесу } \\
\text { об’єднання територіальних } \\
\text { громад }\end{array}$ & $\begin{array}{l}\text { Не всі територіальні громади готові приєднатися до більш } \\
\text { «могутнього сусіда» }\end{array}$ \\
\hline 4 & $\begin{array}{l}\text { Передавання громадам } \\
\text { невластивих їм функцій }\end{array}$ & $\begin{array}{l}\text { Більшість територіальних громад не готові розвивати освітньо- } \\
\text { методичний компонент чи організовувати соціально значущі } \\
\text { справи через брак навичок і досвіду }\end{array}$ \\
\hline 5 & $\begin{array}{l}\text { Втрата державного } \\
\text { контролю }\end{array}$ & $\begin{array}{l}\text { «Зависання» владної вертикалі на рівні великих і середніх міст } \\
\text { в умовах слабкості інститутів громадянського суспільства поза } \\
\text { межами великих міст та порушення законодавства } \\
\text { нецільовим використанням коштів }\end{array}$ \\
\hline 6 & $\begin{array}{c}\text { Ризики, пов’язані } \\
\text { з необхідністю перегляду } \\
\text { меж адміністративно- } \\
\text { територіальних одиниць } \\
\text { (з метою забезпечення їх } \\
\text { фінансової спроможності) }\end{array}$ & $\begin{array}{l}\text { Добровільний характер об’єднання не гарантує } \\
\text { систематичного застосування відповідних норм. } \\
\text { Можлива активізація та радикалізація політичних об’єднань, } \\
\text { які представляють інтереси меншин, що мають компактний } \\
\text { характер проживання }\end{array}$ \\
\hline 7 & $\begin{array}{c}\text { Ризики для бюджетної } \\
\text { системи країни }\end{array}$ & $\begin{array}{l}\text { Загроза зриву фінансування повноважень органів місцевого } \\
\text { самоврядування через скорочення дотацій вирівнювання. } \\
\text { Висока ймовірність закладання в місцеві бюджети заздалегідь } \\
\text { нереальних витрат }\end{array}$ \\
\hline
\end{tabular}




\begin{tabular}{|c|c|c|}
\hline & & Закінчення табл. 2 \\
\hline 1 & 2 & 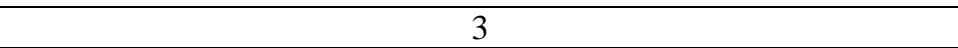 \\
\hline 8 & $\begin{array}{c}\text { Поглиблення диспропорцій } \\
\text { економічного та соціального } \\
\text { розвитку територій }\end{array}$ & $\begin{array}{l}\text { У разі скорочення субвенцій у межах політики регіонального } \\
\text { розвитку }\end{array}$ \\
\hline 9 & $\begin{array}{c}\text { Спекуляція поняттям } \\
\text { «самодостатності ОТГ» }\end{array}$ & $\begin{array}{l}\text { ПДФО має надходити до місцевого бюджету за місцем } \\
\text { реєстрації особи, а не за юридичною адресою їі роботодавця }\end{array}$ \\
\hline 10 & $\begin{array}{c}\text { Зниження якості місцевого } \\
\text { управління та легітимності } \\
\text { прийняття рішень }\end{array}$ & $\begin{array}{l}\text { Загальний низький рівень компетентності службовців } \\
\text { місцевого самоврядування. } \\
\text { Недосконала система відбору депутатського корпусу місцевих } \\
\text { рад }\end{array}$ \\
\hline
\end{tabular}

У результаті аналізу низки ризиків та недоліків децентралізаційних процесів у бюджетній системі України є підстави стверджувати, що бюджетна децентралізація більшою мірою сприяє зростанню дохідного потенціалу регіонів, якісному й обгрунтованому задоволенню соціальних потреб населення на місцевому рівні, забезпеченню обгрунтованого розподілу фінансових ресурсів між окремими територіальними утвореннями. Отже, встановлення ефективної системи місцевих фінансів в Україні безпосередньо залежить від ефективності розвитку системи бюджетної децентралізації та подолання системних ризиків, що мають місце у процесі їі впровадження.

Варто зазначити, що ефективною реформа буде в тому випадку, коли впровадиться «децентралізовано» на місцях громадянським суспільством, а держава забезпечуватиме її виконання, а не навпаки [8]. Складність подальшого розвитку України полягає у необхідності в непростих умовах та в досить стислий термін розв'язати важливе для майбутнього країни завдання - створити власну систему територіальної організації влади, яка б відповідала сучасним викликам розвитку, діяла в інтересах і під контролем громадян.

3 одного боку, здійснення децентралізації $€$ необхідним кроком 3 огляду на євроінтеграційний зовнішньополітичний курс держави. 3 другого - трансформація державного устрою може створити нові виклики для українського суспільства, особливо у процесі здійснення адміністративно-територіальної реформи та на перших етапах функціонування нової системи організації влади.

Висновки та перспективи подальших досліджень. За результатами дослідження можемо стверджувати, що вплив бюджетної децентралізації на економічну безпеку регіону є очевидним. Вдало здійснена бюджетна децентралізація сприятиме нарощенню фінансового потенціалу територій, активізації інвестиційної діяльності, стимулюванню підприємницької активності, зміцненню економічного потенціалу регіону. Економічно активніші громади (громади міст обласного значення) отримають розширення ресурсної бази, оскільки більшість їхніх доходів залишиться у місцевих бюджетах. Громади ізольованих сільських районних бюджетів, які мають вужчу податкову базу, де можливості збору нових податків (податку на нерухомість, місцевого акцизу тощо) є значно меншими, відчують негативні наслідки від реформи (більший стрес), оскільки ресурсна база таких бюджетів лише скоротиться. Реалізація процесу бюджетної децентралізації стимулюватиме їх до пошуку додаткових власних ресурсів, активізації внутрішнього потенціалу, збалансування потреб та можливостей, що $є$ необхідною умовою прискорення соціально-економічного розвитку й гарантування економічної безпеки регіону.

Бюджетна децентралізація може поглибити диференціацію у рівнях розвитку регіонів, призвести до зростання витрат на надання суспільних послуг для невеликих територій у випадку поширення «ефекту масштабу», сприяти виникненню зовнішніх ефектів: «переливу та переповнення», при реалізації місцевих соціальних трансфертів може викликати ефект «перегонів на виживання», мінімізувати ефективність контролю централізованої влади за бюджетним процесом на місцевому рівні, сприяти зростанню корупції, якщо політична конкуренція на місцевому рівні обмежена. Отже, під час розширення повноважень органів місцевого самоврядування щодо прийняття управлінських рішень стосовно формування й використання бюджетних ресурсів варто чітко розуміти переваги та ризики від реалізації політики бюджетної децентралізації, визначити необхідний і достатній рівні ії впровадження. Тому для забезпечення однієї із цілей децентралізації - поліпшення фінансової спроможності громад необхідним є подальший пошук нових шляхів та механізмів удосконалення цієї реформи.

\section{Список використаної літератури:}

1. Бондаревська O.M. Проблеми та перспективи бюджетної децентралізації в умовах трансформації економіки / О.М. Бондаревська // Інноваційний інформаційний простір в освітній і науковій діяльності: проблеми становлення, особливості організації, ефективність та перспективи розвитку : матеріали Міжнар. наук.-практ. конф., присвяч. 10-річчю Центрально-Свропейського ун-ту, 19-21 листоп. 2014 р. - Кошице, 2014. - C. $25-29$. 
2. Бикадорова Н.О. Фінансова децентралізація місцевого самоврядування / Н.О. Бикадорова // Економічний вісник Донбасу. - 2010. - № 2 (20). - С. 145-151.

3. Возняк Г.В. Переваги та ризики бюджетної децентралізації: теоретико-методологічні аспекти / Г.В. Возняк // Проблеми економіки. - 2015. - № 2. - С. 253-255.

4. Гонта O.I. Проблеми диспропорційності економічного зростання національного господарства України та іiі окремих регіонів / O.I. Гонта // Проблеми і перспективи економіки та управління. - 2018. - № 2 (14). - С. $57-63$.

5. Заяць T.A. Розвиток сільських поселень України в умовах децентралізації: можливості та ризики / T.A. Заящь // Демографія та соціальна економіка. - 2017. - № 3 (31) - С. 48-60.

6. Заяць T.A. Просторовий розвиток регіонів та поселенських структур: безпековий аспект / T.A. Заящь, Г.О. Краєвська, Т.Г. Кравиова // Ефективна економіка. - 2018. - № 11 [Електронний ресурс]. - Режим доступу : http://www.economy.nayka.com.ua/pdf/11_2018/5.pdf.

7. Онищенко С.В. Бюджетна безпека України: сутність, загрози та шляхи забезпечення : монографія / C.В. Онищенко. - К. : Знання України, 2017. - 238 с.

8. Онищенко В.О. Фінансова децентралізація як інструмент забезпечення економічної безпеки / В.О. Онищенко, О.М. Бондаревська // Економічна безпека: держава, регіон, підприємство : матеріали II Всеукр. наук.-практ. Інтернет-конф., 15 груд. 2015 р. - 15 січня 2016 р. - Полтава : ПолтНТУ, 2016. - С. 8-10.

9. Онищенко В.О. Бюджетна децентралізація: переваги, недоліки, перші здобутки / В.О. Онищенко, O.M. Бондаревська // Розвиток фінансового ринку в Україні: проблеми та перспективи : матеріали IV Всеукраїнської науково-практичної інтернет-конференції - Полтава : ПолтНТУ, 2016. - С. 9-11.

10. Про місцеве самоврядування в Україні : Закон України від 21.05.1997 № 280/97-вр зі змінами i доповненнями // Законодавство України : офіц. вебсайт Верховної Ради України [Електронний ресурс]. Режим доступу : http://zakon5.rada.gov.ua/laws/show/280/97-вр.

11. Da Silva M. Intergovernmental Reforms in the Russian Federation / Da Silva M. et. al. - Washington, D.C. : The World Bank, 2009.

\section{References:}

1. Bondarevs'ka, O.M. (2014), «Problemy ta perspektyvy bjudzhetnoi' decentralizacii' v umovah transformacii' ekonomiky», Innovacijnyj informacijnyj prostir v osvitnij i naukovij dijal'nosti: problemy stanovlennja, osoblyvosti organizacii', efektyvnist' ta perspektyvy rozvytku, materialy Mizhnar. nauk.-prakt. konf., prysvjach. 10-richchju Central'no-Jevropejs'kogo un-tu, Koshyce, pp. 25-29.

2. Bykadorova, N.O. (2010), «Finansova decentralizacija miscevogo samovrjaduvannja», Ekonomichnyj visnyk Donbasu, No. 2 (20), pp. 145-151.

3. Voznjak, G.V. (2015), «Perevagy ta ryzyky bjudzhetnoi' decentralizacii': teoretyko-metodologichni aspekty», Problemy ekonomiky, No. 2, pp. 253-255.

4. Gonta, O.I. (2018), «Problemy dysproporcijnosti ekonomichnogo zrostannja nacional'nogo gospodarstva Ukrai'ny ta i'i' okremyh regioniv», Problemy i perspektyvy ekonomiky ta upravlinnja, No. 2 (14), pp. 57-63.

5. Zajac', T.A. (2017), «Rozvytok sil's'kyh poselen' Ukrai'ny v umovah decentralizacii': mozhlyvosti ta ryzyky», Demografija ta social'na ekonomika, No. 3 (31), pp. 48-60.

6. Zajac', T.A. (2018), «Prostorovyj rozvytok regioniv ta poselens'kyh struktur: bezpekovyj aspekt», Efektyvna ekonomika, No. 11, [Online], available at: http://www.economy.nayka.com.ua/pdf/11_2018/5.pdf

7. Onyshhenko, S.V. (2017), Bjudzhetna bezpeka Ukrai'ny: sutnist', zagrozy ta shljahy zabezpechennja, monografija, Znannja Ukrai'ny, Kyiv, 238 p.

8. Onyshhenko, V.O. and Bondarevs'ka, O.M. (2016), «Finansova decentralizacija jak instrument zabezpechennja ekonomichnoi' bezpeky», Ekonomichna bezpeka: derzhava, region, pidpryjemstvo, materialy II Vseukr. nauk.prakt. Internet-konf., PoltNTU, Poltava, pp. 8-10.

9. Onyshhenko, V.O. and Bondarevs'ka, O.M. (2016), «Bjudzhetna decentralizacija: perevagy, nedoliky, pershi zdobutky», Rozvytok finansovogo rynku v Ukrai'ni: problemy ta perspektyvy, materialy IV Vseukrai'ns'koi' naukovo-praktychnoi' internet-konferencii', PoltNTU, Poltava, pp. 9-11.

10. Verhovnoi' Rady Ukrai'ny (1997), «Pro misceve samovrjaduvannja v Ukrai'ni», Zakon Ukrai'ny vid 21.05.1997 № 280/97-vr zi zminamy i dopovnennjamy, Zakonodavstvo Ukrai'ny, ofic. veb-sajt Verhovnoi' Rady Ukrai'ny, [Online], available at: http://zakon5.rada.gov.ua/laws/show/280/97-vr

11. Da Silva, M. et. al. (2009), Intergovernmental Reforms in the Russian Federation, in Washington, D.C., The World Bank.

Бондаревська Ольга Миколаївна - кандидат економічних наук, старший викладач кафедри фінансів, банківського бізнесу та оподаткування Національного університету «Полтавська політехніка імені Юрія Кондратюка».

Наукові інтереси:

- економічна безпека регіону;

- бюджетна децентралізація;

- міжбюджетні відносини;

- об'єднані територіальні громади.

E-mail: olia.bondarevska@gmail.com. 